\title{
The Wonderful World of Privileges
}

\section{- The Par Condicio Creditorum vs. Closeout-Netting}

by

\author{
Christoph G. Paulus*
}

Speaking about privileges arouses sentiments which are not necessarily without ambivalence. Even though the primary connotation might be positive, a closer look reveals that there are also downsides. That, here too, the coin consists of two sides is most prominently evidenced by the well known term 'privilegium odiosum' which indicates that the one's elevation is (or might be) the other's anger. The primary example is the gracious royal permission to the medieval Jewish bankers to demand interests from Christians. Those bankers (and their fellow Jews in general) had thoroughly to suffer from this privilege. Yet, irrespective of this closely intertwined ambivalence, privileges are throughout history and roughly all over the globe objects of desire - after all, they grant a special status be it socially, be it economically or however else. The combination of these two sides is likely to be the real reason why, generally speaking, privileges are rarely addressed openly, at least not by those who are benefitting from them; they normally try to justify their elevated status as something necessitated by some superior order or to disguise it as something actually normal or to bide it throughout.

Table of Contents $\quad$ ECFR 2014, 531- 553

I. Introduction . . . . . . . . . . . . . . . . . . . . . . . . . 532

II. Some thoughts about par condicio creditorum $\ldots \ldots \ldots \ldots \ldots \ldots 33$

1. Dogmatics . . . . . . . . . . . . . . . . . . . 534

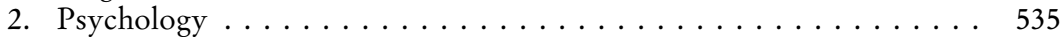

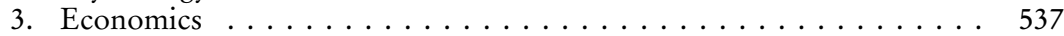

III. Privileges . . . . . . . . . . . . . . . . . . . . . . . . . 539

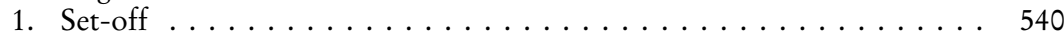

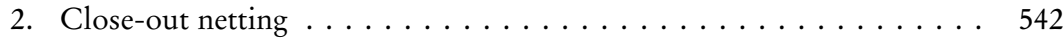

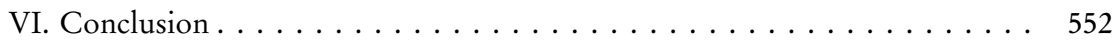

* Professor, Humboldt-Universität zu Berlin, Institute für Interdisziplinäre Restrukturierung e.V. This article is based on a talk presented by the author at the Max Planck Institut for International, European and Regulatory Procedural Law in Luxembourg on 16 April 2014. I thank the audience for a prolific and stimulating discussion; furthermore, I am most grateful to the valuable comments by Profs. Heribert Hirte and Stanislaw Soltysinki on the draft of this article. My assistent, Stephan Rauch, helped me very much with research for this article. 


\section{Introduction}

Speaking about privileges arouses sentiments which are not necessarily without ambivalence. Even though the primary connotation might be positive, a closer look reveals that there are also downsides. That, here too, the coin consists of two sides is most prominently evidenced by the well known term 'privilegium odiosum' which indicates that the one's elevation is (or might be) the other's anger. The primary example is the gracious royal permission to the medieval Jewish bankers to demand interests from Christians. Those bankers (and their fellow Jews in general) had thoroughly to suffer from this privilege. Yet, irrespective of this closely intertwined ambivalence, privileges are throughout history and roughly all over the globe objects of desire - after all, they grant a special status be it socially, be it economically or however else. The combination of these two sides is likely to be the real reason why, generally speaking, privileges are rarely addressed openly, at least not by those who are benefitting from them; they normally try to justify their elevated status as something necessitated by some superior order or to disguise it as something actually normal or to hide it throughout.

These are old patterns of human behaviour that can be found everywhere on the globe and over all historical periods. ${ }^{1}$ Here and now, a particular emanation of this phenomenon can be traced in the treatment of credit institutions in law - and this is what shall be addressed by the following remarks. To be sure, with regard to the German legal system, credit institutions' liabilities for correct treatment of their customers has been - and still is - aggravated particularly by the Private Law Federal Supreme Court's (BGH) case law. The increasing amount of information duties and transparency measures to be provided by credit institutions to their customers according to this adjudication is even close to something opposite to a privilege. ${ }^{2}$ However, if one shifts the perspective just a little bit, a privilege becomes visible in the relationship of the credit institutions to their customers. A striking emanation ${ }^{3}$ is to be found in insol-

1 As an historical and psychological aside: the still today wide-spread fear from the evil eye is the fear from envy; many remedies have been invented to protect oneself from such eye's devastating effect; for ancient Rome cf. Paulus, Römisches Eigentumsverständnis und Aberglaube, Revue Internationale des Droits de l'Antiquitè (RIDA) XLIII 1996, S. $283 \mathrm{ff}$.

2 See just Emmerich in: Münchener Kommentar-BGB, 6th ed., 20012, \$311, marg. no. $112 \mathrm{ff}$; Grundmann, ibid. $\$ 276$ marg. no. $114 \mathrm{ff}$.

3 Another privilege is to be found in the deposit business of current accounts; it is commonly qualified as being a depositum irregulare (cf. Henssler in: Münchener KommentarBGB, 6th ed., 2012, $\$ 700$ no. $15 \mathrm{ff}$.) which, pursuant to sec. $700 \mathrm{BGB}$, permits the credit institution to use the deposed money more or less for free. This privilege opens opportunities to create new money (on this, see M.Köhler, Die Wertstabilität des Geldes als 
vency law where the fundamental baseline of equal treatment of creditors (par condicio creditorum) is replaced by a privileged status.

It is, thus, appropriate to begin the following considerations with some thoughts about the principle of the creditors' equal treatment and why it is so central for insolvency law (II). This shall be followed by the discussion of privileges (III). In the last section (IV) some deliberations are presented that give some cautious (and very preliminary) guidance as to how to deal with those privileges.

\section{Some thoughts about par condicio creditorum}

Given its often ${ }^{4}$ proclaimed central role for insolvency law, it appears to be appropriate to start with some thoughts about the just mentioned principle of equal treatment of the creditors (alternatively: pari passu principles), in particular, whether or not it is rightfully seen as a core principle. After all, despite its alleged centrality, there is no explicit mention to be found neither in the German Insolvency Ordinance ( $\mathrm{Ins} \mathrm{O}$ ) nor in many other insolvency codes around the world. Quite to the contrary, the history of bankruptcy legislation could even be delineated as a never-ending fight for privileges. ${ }^{6}$ To name but one example: For literally centuries, ${ }^{7}$ the sovereign as legislator has (ab)used its power of rule-setting to grant itself as executive a bankruptcy

Inhalt der Vertragstreue und die Eigentumsgarantie, JZ 2013, 957, 962 ff.), for instance, by means of overnight transactions such as repo-trading.

4 See just Häsemeyer, Insolvenzrecht, 4th ed., 2007, 2. 24 ff.; Prütting, Allgemeine Verfahrensgrundsätze der Insolvenzordnung, in: Kölner Schrift zur Insolvenzordnung, 3rd ed., 2009, Kapitel I marg. no. 61 ff., p. 19 ff.; Brinkmann, The Position of Secured Creditors in Insolvency, in: Eidenmüller/Kieninger (eds.), The Future of Secured Credit in Europe, 2008, 249, $250 \mathrm{f}$. Rather sceptical, however, Knospe, Scharfes Schwert oder harmlose Gerechtigkeitsregel? - Die insolvenzrechtliche Monstranz der Gläubigergleichbehandlung, ZInsO 2014, $861 \mathrm{ff}$.

5 On this particular principle's central role in the present practice of sovereign debt restructuring, see Sandrock, Griechenland und Zypern in der Finanzkrise: die Rechtsstellung ihrer privaten Finanzinvestoren, RIW 2014, 16 ff.; Paulus, Jüngste Entwicklungen im Resolvenzrecht, WM 2013, 489 ff.; ders., ZIP 2013, Resolvenzrecht im Werden NML, Inc. vs. Argentina, 2. Runde, ZIP 2013, 2190 ff. See, additionally, below text around and footnotes 19 and 20.

6 Cf., for instance, etwa J. Bauer, Ungleichbehandlung der Gläubiger im geltenden Insolvenzrecht, DZWIR 2007, 188.

7 See, for instance, sec. 13 of the famous Freiburg Town Charter "Nüwen Stattrecht und Statuten der loblichen Stadt Fryburg im Pryzgow gelegen" from 1520 (drafted by Ulrich Zasius). On this, cf. Knoche, Ulrich Zasius und das Freiburger Stadtrecht von 1520, 1957, p.75; Nassall, Das Freiburger Stadtrecht von 1520 - Durchsetzung und Bewährung, 1989 , p. $206 \mathrm{ff}$. 
privilege $^{8}$ in the form of what was called sometimes "prince's penny" sometimes "crown's privilege" and sometimes "fisc privilege". Germany" is currently one of the few jurisdictions in this world where this privilege is (allegedly ${ }^{10}$ ) abolished; ${ }^{11}$ but, telling enough, the fisc fought ever since the privilege's abolition in 1999 until today for its re-introduction. ${ }^{12}$

\section{Dogmatics}

A closer look into the principle reveals that differentiations are necessary: after all, equal treatment might refer to the procedural steps within a insolvency proceeding or, alternatively and additionally, to the distribution process. Besides of procedural rights granted to all insolvency creditors - as defined in sec. $38 \mathrm{Ins} \mathrm{O}$ - who are to pursue their satisfaction exclusively within the insolvency procedure, sec. $87 \mathrm{Ins} \mathrm{O},{ }^{13}$ suffice it to mention here the plan proceeding alone. ${ }^{14}$ Even though this modern instrument introduces private autonomous flexibility ${ }^{15}$ into insolvency law which has served for centuries, if not millennia, as paradigm of the strict to be applied rigor iuris it obliges the drafters to procedural equal treatment in sec. 222, $226 \mathrm{Ins} \mathrm{O} .{ }^{16}$

8 Informative on this, by far not unique, method H.Lang, Gesetzgebung in eigener Sache, 2007.

9 Others are, for instance, Austria (which served as model for Germany) or England.

10 Cf. J.-P. Meier, Privilegien des Fiskus und der Sozialversicherungsträger in der Unternehmensinsolvenz, 2010, passim.

11 See also infra at III 2.

12 Occasionally by means which were not entirely beyond any doubt regarding their legitimacy, cf. Vallender, Par conditio creditorum ade?, NZI 2005, 599 ff.; Marotzke, Die Anfechtbarkeit von Vollstreckungsmaßnahmen wegen Benachteiligung konkurrierender Gläubiger, ZInsO 2006, 7 ff.; idem, Ketzerisches aus der ersten Instanz, ZInsO 2006, 190 ff.; ders., Der insolvenzrechtliche Gläubigergleichbehandlungsgrundsatz in der neueren Rechtspolitik, Insolvenzjahrbuch 2007, 10 ff.; idem, Sinn und Unsinn einer insolvenzrechtlichen Privilegierung des Fiskus - zugleich eine Stellungnahme zu Art. 3 des Haushaltbegleitgesetzes 2011 i. d. F. des Gesetzesbeschlusses des Deutschen Bundestages vom 28.10.2010, ZInsO 2010, 2163 ff.; J.-P. Meier, Die Wiedereinführung von Insolvenzvorrechten durch das Hauptportal, ZInsO 2010, 1121.

13 On this cf. BGH, dec. from 29 Jan. 2009 - III ZB 88/07, ZInsO 2009, 662; OLG Stuttgart, dec, from 5 Nov. 2013 - 1 Sch 2/11, ZInsO 2014, 720, 721.

14 This is all the more permissible as there has been published only recently a comprehensive study on this subject, cf. Kodek, Der insolvenzrechtliche Gleichbehandlungsgrundsatz in vergleichender Perspektive - eine Skizze, KTS 2014, 215.

15 On the discussion about the contractual nature or facet of the insolvency plan, see primarily Madaus, Der Insolvenzplan, 2011.

16 Madaus, ZIP 2014, 500, $506 \mathrm{ff}$., correctly admonishes the insolvency court of the Suhrkamp case in Berlin to take this into account when sanctioning the plan in that proceeding. 
With regard to the distribution equality, above all, the abolition of privileges in the German Insolvency Ordinance comes to mind. Following the Austrian model (and thereafter copied by several other jurisdictions such as the English one), sec. $38 \mathrm{InsO}$ refrains from any distinction between unsecured creditors; they share the same rank. This implies that, of all possible distribution methods in cases of a common pool problem, each creditor is to receive the same proportional dividend. ${ }^{17}$

\section{Psychology}

If this more or less positivistic explanation should not suffice, at least two others are possible: a psychological one and an economic one. As to the first, ${ }^{18}$ the question arises when, for instance, investment bankers tell that, before going into a certain country, they examine the effectiveness and efficiency of the local enforcement and insolvency law. Why do they do that, given the fact they know perfectly well that their investment might yield profit or might be lost? What is it that makes them want to be treated in the worst case scenario of an insolvency proceeding efficiently and effectively? The return will anyway be low if not zero.

It is my assumption that here is a fundamental feeling of fairness at stake which behavioural economists have made likely decades ago when they started to examine all over the world the result of the so called ultimatum game. ${ }^{19}$ Two test-persons were put together and one of them was given $€ 100$ with the order to divide this money between her and the other test-person in whatever proportion. When and if the other test-person agrees to that distribution they both were allowed to keep the money. Otherwise they would have to return it to the investigator. The economists expected as result that this division would be something like $€ 1$ for the other person and the original recipient of the money would keep $€ 99$. After all, the other one would receive $€ 1$ for just saying "okay".

17 On this, cf. Paulus, Freiheit und Gleichheit als Grenzmarkierung zwischen Zivilrecht und Insolvenzrecht, in: Beuthien/Fuchs/Roth/Schiemann/Wacke (eds.), Perspektiven des Privatrechts am Anfang des 21. Jahrhunderts - Festschrift für Dieter Medicus zum 80. Geburtstag, 2009, p. $281 \mathrm{ff}$.

18 As to what follows, see Paulus, Ist das Insolvenzrecht wirklich eine Schlüsselmaterie für die Wirtschafts- und Finanzstabilität eines Landes? - Der Versuch einer Antwort, in: Dahl/Jauch (eds.), Festschrift für Klaus Hubert Görg, 2010, p. 361 ff.

19 The literature has grown endlessly; therefore, just as an "appetizer" Lebrer, Wie wir entscheiden - Das erfolgreiche Zusammenspiel von Kopf und Bauch, 2009, 232; Siegmund / Fehr / Nowak, Teilen und Helfen - Ursprünge sozialen Verhaltens, Spektrum der Wissenschaft - Dossier, issue 5 / 2006, p. 55. 
However, the factual result was almost diametrically opposed to that expectation - and has been repeated over and over again all over the globe: If the original recipient would not offer either half of the $€ 100$ or something close to $50 \%$, the other one would reject (fifty-fifty is a wide-spread distribution scheme but there are some regions in the world with a different understanding of fair distribution). The conclusion drawn from this game is the assumption that humans do have a fundamental feeling for fairness. It is not icy egoism that dominates exclusively inter-human cohabitation but there is also a kind of sensibility for the others' expectations and one's own adjusted behaviour to them.

If this conclusion is valid - after all the game has been tested around the world innumerable times ever since - one might be justified to see here an explanation for the importance of an efficient insolvency proceeding. After all, it appears to comply with a fundamental feeling of justice that of all distribution methods the equal sharing is the most appropriate one. If I have to suffer a loss due to my debtor's inability to pay me, such loss should be also borne in the same way by my co-creditors. To be sure, the loss is part of the business risk; however, this risk should be transparent and fairly distributed between all stake-holders.

It is in this context that the uneasiness begins with quite a famous case engaging in these days the courts of the United States. ${ }^{20}$ As of now, it seems as if NML Capital, commonly called a vulture fund, will receive full satisfaction whereas other creditors of Argentinian bonds who have consented to a haircut will receive only partial satisfaction. The issue at stake is the exact meaning of the pari passu principle ${ }^{21}$ which is just another term of art for the equal treatment of creditors. The creditor, NML, who has bought bonds at a steep discount due to the dropped prices in the wake of restructuring efforts of the debtor, Argentina, and its subsequent agreements with creditors on a reduc-

20 NML Capital, Ltd. vs. Argentina, see above at fn 5. For NML'S efforts in Europe cf. Audit, Sovereign Bonds and National Relativism: Can New York Law Contracts Safely Cross the Atlantic?, forthcoming Capital Market L.J. 2014; available at: http://papers.ssrn.com/sol3/papers.cfm?abstract_id=2396856.

21 On this clause, cf. Olivares-Caminal, To Rank Pari Passu or Not to Rank Pari Passu: That is the Question in Sovereign Bonds After the Latest Episode of the Argentine Saga, 15 Law and Business Review of the Americas 2009, 745 ff.; idem., The Pari Passu Interpretation in the Eliott Case: A Brilliant Strategy but an Awful (Mid-Long Term) Outcome? 39 Hofstra Law Review 2011, 39 ff. Additionally, Panizza, Do We Need a Mechanism for Solving Sovereign Debt Crises? A Rule-Based Discussion, sub II, in: Paulus (ed.), A Debt Restructuring Mechanism for Sovereigns - Do We Need a Legal Procedure?, to appear in 2014. See also Chabot/Gulati, Santa Anna and His Black Eagle: The Origins of Pari Passu?, available at: http://papers.ssrn.com/sol3/papers.cfm?abstract_id=2397929. 
tion of the face value are now claiming payment in full and seem to succeed. The courts (and the law?) make this success of selfish behaviour - champerty possible but leave a bad after-taste.

\section{Economics}

A final approach to understanding the key function of the par condicio creditorum is an economic one. Accordingly, the question to be raised in the beginning is a hypothetical: what if there were no insolvency law at all? In such a scenario, it is to be assumed that the best informed creditors would receive full satisfaction whereas the others would be left with little or nothing. The priority principle prevails which allows the first to come to become served first - in full. This means there is no equality at all in distribution. Supposing the above given psychological explanation as being valid, it is further quite likely that potential creditors would abstain from investing into the particular debtor unless granted full transparency from the debtor. But as a whole, it is to be assumed that the risk of belonging to the "losers" would in most if not all cases be calculated as being too high. Historical and present day examples can serve as proof: In $1512^{22}$ the town fathers of Antwerp - then the economic capital of entire Europe - wrote a letter to the later emperor Charles V. asking him for permission to enact a bankruptcy law. Their argument was that otherwise the "dear foreign merchants" would leave the city since they lost too much to unfaithful debtors. The permission to enact such law not only gave birth to a remarkable piece of legislation but also initiated a wave of bankruptcy legislation that stretched from other Dutch cities to France (Lyon) and England (Henry VIII). The modern example is the inclusion of "insolvency and creditor rights" into the elaterin compendium of twelve key standards established by the Financial Stability Board. ${ }^{23}$ The purpose of that list is, in the words of the Board's website:

The Compendium of Standards lists the various economic and financial standards that are internationally accepted as important for sound, stable and well functioning financial systems. The international community attaches much importance to the adoption and implementation of these standards because of their beneficial effects on the stability of financial systems both inside countries and globally.

This means that this Board is of the opinion that a modern and effective insolvency regime is key for a prospering economy all over the world. The UNCITRAL Legislative Guide describes this as:

22 On this, see more elaborate Paulus, Ein Kaleidoskop der Geschichte des Insolvenzrechts, JZ 2009, $1148 \mathrm{ff}$.

23 Cf. http://www.financialstabilityboard.org/cos/key_standards.htm. 
Insolvency laws and institutions are critical to enabling States to achieve the benefits and avoid the pitfalls of integration of national financial systems with the international financial system. Those laws and institutions should promote restructuring of viable business and efficient closure and transfer of assets of failed businesses, facilitate the provision of finance for start-up and reorganization of businesses and enable assessment of credit risk, both domestically and internationally. ${ }^{24}$

Whereas the total lack of an insolvency system, thus, would lead to rather unpleasant economic consequences, let us assume what it means within a functioning and effective insolvency system to have a privileged position. Privilege in this context means to get full satisfaction even within an insolvency proceeding before any one of the general unsecured creditors receives any dividend. The insolvency risk, thus, is mitigated and the respective creditor can be more relaxed in observing and controlling his or her debtor. It was exactly this relaxation which had served the German legislator as argument to abolish the fisc privilege ${ }^{25}$ and to impose the position of a general unsecured creditor on tax authorities pursuant to sec. $38 \mathrm{InsO}$. Since tax authorities are usually the first to recognize a person's inability to pay its obligations. Being equipped with a privilege they could be mild and adopt a wait-and-see policy. In the effort to come to earlier commencements of insolvency cases, the "taxnon-payment" indicator was supposed to become instrumentalised and to have the tax authorities filing earlier a petition.

The relaxation issue is what will be addressed below (at C II) when the privilege of close-out netting will be discussed. Therefore, it should be kept in mind for now that privileges imply a diminution of the need to control the debtor. This is not in itself good or bad; to be sure, the control can possibly impede the debtor's activities and transform it into a puppet-on-the-string of the creditor - a phenomenon well known in company and tax law (shadow director etc.). On the other hand, to impose control duties on, for instance, the debtor's workers would mean to burden them with the more than unpleasant task to possibly deprive themselves from the cow that feeds them, as it were. But there are certainly creditors that are particularly apt to exercise such control. We will come back to this.

Finally, let us have a look at the equal treatment principle, the par condicio creditorum. Here, creditors do bear the insolvency risk - however, they all share this fate. ${ }^{26}$ In order to minimize the risk, yet, they will check carefully with whom they enter into transactions and, once done so, they will monitor the debtor closely in order to have the chance to react quickly in case of need. This is all the more imperative as there is additionally the shadow of insol-

24 Legislative Guide on Insolvency Law, 2005, p. 9 and 10.

25 Cf. Balz/Landfermann, Die neuen Insolvenzgesetze, 2nd ed., 1999, p. $161 \mathrm{f}$.

26 On this, see also Skeel/Jackson, Transaction Consistency and the New Finance in Bankruptcy, 112 Columbia L.R. 152, 185 ff. (2012). 
vency's avoidance powers at stake: transactions in the period of three months preceding the petition are subject to a more (sec. 131, $132 \mathrm{InsO}$ ) or less (sec. $130 \mathrm{Ins} \mathrm{O}$ ) strict regime of recovery. ${ }^{27}$ Thereby, the principle of equal treatment is extended into the period prior to the commencement of the case..$^{28}$ The consequence therof is that creditors, from a point of time unknown ex ante, share an obligation towards each other to respect the interests of the cocreditors. It is perfectly understandable that individual creditors do see this imposition as a major impediment to their activity; after all, control does not come for free. However, abstracting from the individual creditors the check and balance system between debtor and creditors has its advantages for the general good. ${ }^{29}$ An effective insolvency system exercises, thus, a disciplinary function of the market participants and provides incentives for responsible lending and borrowing. ${ }^{30}$

The alternative to such a creditor-monitoring system would be that state authorities or whichever other institutions do such monitoring. To a certain degree, this is the very task of the rating agencies; ${ }^{31}$ and there have been - and there still are - numerous jurisdictions which, as a matter of fact, do employ such state institutions. ${ }^{32}$ However, not only that this demands an enormous bureaucracy and creates, thus, considerable costs; it depends also very much on the size of the particular country how effective such authority can work.

\section{Privileges}

Speaking about privileges in the German insolvency law might be somewhat surprising. Since it is one of the outstanding achievements of the German Insolvency Ordinance from 1999 that claimed to have realized the par condicio creditorum by having abolished all privileges, including (and in particular) the

27 On the present discussion on the right balance of the German rules on avoidance see, for instance, Marotzke, Vertrauensschutz kontra Gesamtgläubigerinteresse - Gedanken zu Auslegung und Reform des Insolvenzanfechtungsrechts, ZInsO 2014, $417 \mathrm{ff}$.

28 See below fn. 54 .

29 It might be noted as an aside that the Islamic finance law prohibits a lender to earn interests by the mere elapsing of time. Instead, to make profit the lender has always to bear a certain risk.

30 On these issues cf. Paulus, The Interrelationship of Sovereign Debt and Distressed Banks: A European Perspective, 49 Tex. Int'l L.J., 201 ff. (2014).

31 See just Schroeter, Ratings - Bonitätsbeurteilungen durch Dritte im System des Finanzmarkt-, Gesellschafts- und Vertragsrechts, 2014. Cf., additionally, G. Wagner, Die Haftung von Ratingagenturen gegenüber dem Anlegerpublikum, FS Blaurock, 2013, p. $467 \mathrm{ff}$.

32 In Mexico, for instance, it is the ministerio público's task to file petitions whenever it discovers need. 
abovementioned fisc privilege. A closer look, however, reveals that this abolition was not complete; some survived this legislative cap $^{33}$ and of them, $\left(\right.$ only ${ }^{34}$ ) three shall be addressed here in what follows.

\section{Set-off}

It appears to be fair to conclude from the aforegoing discussion that the principle of the creditors' equal treatment in their debtor's insolvency is fundamental and that, consequently, exceptions from this principle need thorough and convincing justification. Having, thus, laid some ground regarding the wisdom and fundamentality of this principle, we can now turn to the privileges which are more or less evidently granted to credit institutions. Thereby, I distinguish between the simple set-off rule (I) and the more advanced closeout netting (II). In order to complete the picture, a few observations about a different set of privileges for such credit institutions will be addressed (III) before some remarks about desirability or necessary changes of the present situation are to conclude the present paper (D)..$^{35}$

Sec. 94 InsO allows any insolvency creditor (as defined in sec. $38 \mathrm{InsO}$ ) to settoff his claim against the debtor's claim when and if, at the time of the proceeding's opening, such set-off right existed through statutory or contractual permission. ${ }^{36}$ Sec. 95 and 96 InsO modify and restrict this right to a certain degree but leave the general principle intact. Without going too deeply into it, I still ${ }^{37}$ see this general principle as expressed in sec. $94 \mathrm{InsO}$ as a privilege - not exclusively, ${ }^{38}$ to be sure, but primarily - for financial institutions. Since just

33 See, in addition to supra fn. 10, Henckel, Die letzten Vorrechte im Insolvenzverfahren, in: Prütting/Vallender (eds.), Insolvenzrecht in Wissenschaft und Praxis, Festschrift Uhlenbruck, 2000, S. $19 \mathrm{ff}$.

34 But see infra at I 4 regarding the current account.

35 A subsequent paper will address some aspects of the evolution of the close-out netting privilege: Paulus, Multinationale Unternehmen und nationale Insolvenzrechte, ZIP 2014.

36 On the various shapes of the right to set-off in different jurisdictions, cf. Zimmermann, Die Aufrechnung - Eine rechtsvergleichende Skizze zum Europäischen Vertragsrecht, in: Beuthin (ed.), Festschrift für Medicus, 1999, p. $707 \mathrm{ff}$.

37 See already Paulus, Zum Verhältnis von Aufrechnung und Insolvenzanfechtung, ZIP 1997, S. 569 ff.; idem, Banken und Insolvenz - eine internationale Betrachtung, ZBB 2002, 492, 494; idem, Rechtspolitisches und Rechtspraktisches zur Insolvenzfestigkeit von Aufrechnungsvereinbarungen, in: Canaris u. a. (eds.), 50 Jahre BGH, Festgabe der Wissenschaft, Bd. III, 2000, p. $765 \mathrm{ff}$.

38 Tax authorities might also benefit quite extensively from this privilege when and if they have a claim against the debtor. 
by looking at the very basic factual situation underlying this rule, one recognizes quickly the dramatic improvement of a creditor's situation who is in the position to set-off over his fellow-creditors without this right or possibility. Those facts are that there are two persons (or entities) $\mathrm{D}$ and $\mathrm{O}$ who happen to be at the same time their mutual creditor and debtor:

\section{1.) Mutual obligations}

If the obligation of the insolvency debtor (D) would be to deliver shoes to the other party $(\mathrm{O})$, whereas - entirely independently on this obligation - $\mathrm{O}$ would happen to be obliged to clean D's garden, it is evident that $\mathrm{O}$ has to lodge his claim regarding the delivery of shoes as a monetary claim and that he will receive a dividend. In turn, since the garden cleaning duty is not based on an executory contract, $\mathrm{O}$ still would have to fulfill his obligation in toto. $\mathrm{O}$ is here in a rather unpleasant situation to be bound to deliver in full but to receive only a part (the dividend) of what is owed to him.

\section{2.) Obligations connected by a synallagmatic contract}

Things change, however, if both obligations were stemming from one and the same synallagmatic contract (in US terminology: executory contract ${ }^{39}$ ) which happens to be not yet completely fulfilled by either side. Here the estatefavoring rule of sec. $103 \mathrm{Ins} \mathrm{O}$ would apply. Accordingly, D's administrator is granted the choice between termination or continuation of the contract; the decision is entirely dependent on an assessment of the economic advantages and disadvantages for the estate. In this case, $\mathrm{O}$ would have at least a chance of better treatment even though with only very limited rights to influence the administrator's decision..$^{40}$

\section{3.) Set-off}

Finally, if both obligations happen to be payment obligations, the creditor $\mathrm{O}$ is in the best possible situation given the fact that his debtor is in an insolvency proceeding: By "sacrificing" his claim he can get full satisfaction on his own without being dependent on anyone's choice or decision! Full satisfaction is otherwise granted only to creditors with a right to separation (Aussonderung), and it should be noted that, under German law, no stay applies to exercising the right to set-off! ${ }^{11}$

39 Sec. 366 US Bankruptcy Code (BC); on this, cf. Countryman, Executory Contracts in Bankruptcy, 57 Minn. L.R. 439 (1973).

40 See sec. 103 InsO (cf. http://www.iuscomp.org/gla/statutes/InsO.htm\#s103) :

41 This is different from sec. 553, 362(a)(7) BC. 
It is true, however, that sec. 94 bestows the right to set-off to all payment creditors; nevertheless, the typical beneficiary of this privilege are quite certainly banks. Again, looking to this right from this angle and to set it in correlation to creditors in a very similar position it appears to be not too easy to find a dogmatic and just explanation for this privileged treatment. ${ }^{42}$ Nevertheless, it is accepted as if it were a superior rule of nature!

\section{4.) Current account}

Be it noted for the present context as well as for the subsequent one of Closeout Netting that even less explicable irregularities are also taken for granted: Sec. 355 HGB (= Trade Law Code) provides for the current account (Kontokorrent) for which it is accepted that all receivables within this relationship are to be deemed as legally non-existent and being replaced by only one claim which remains on balance of all those "non-existent" claims. Insolvency law does accept this artificial (if not fictional) disappearance of otherwise fullfledged claims and concentrates on the one remaining balance claim. ${ }^{43}$ This is what might be called a "hidden privilege"; it is not especially adapted to the needs of the financial industry but rather to those of entrepreneurialship.

\section{Close-out netting}

\section{a. Definition and elements}

The technical term of netting comprises different meanings: there is the settlement netting, the novation netting, and the close-out netting (in German: Liquidationsnetting). Only the latter shall be addressed in what follows as this form of netting is by far the most wide-spread one and carries with it the most important implications in cases of insolvency; after all, it serves as a protective shield for the gigantic market of derivatives, swaps, repurchase contracts ("repos") and other new financial products trading which had increased almost exponentially in the years preceding the last financial crisis. This protective function is more than likely to be the reason why this type of netting is quite unique in being pushed forward by hard and constant lobby work. It is in particular the International Swaps and Derivatives Association

42 There are some attempts, cf., for instance, Jeremias, Internationale Insolvenzaufrechnung, 2004, p. 117 ff., 123 f.; Peitsch, Die Insolvenzaufrechnung, 2001, p. 157 ff.

43 Just see Brandes/Lohmann, MüKo-InsO, 3rd ed., $\$ 96$ marg. no. 32. On a broader perspective, see also Hirte, Gegenstand vs. Wert - Von den Schwierigkeiten des Unternehmensrechts mit der zivilrechtlichen Dogmatik, FS Hofmann-Becking, 2013, p. $531 \mathrm{ff}$. 
(ISDA $)^{44}$ that serves here as a never resting promoter of further improvements of risk-alleviations of such netting agreements. ${ }^{45}$

The exact definition of close-out netting seems to be hard to give. One example is that it means "the determination of the debt owed after the netting of the market values of all pending obligations and offsetting that final result with outstanding payments and deliveries, if existent." 46 An alternative and more exhaustive example is given in art. 2 par. 1 lit n) of the Directive 2202/47/EC of the European Parliament and of the Council of 6 June 2002 on financial collateral arrangements (Finanzsicherheitenrichtlinie):

'close-out netting' provision means a provision of a financial collateral arrangement, or of an arrangement of which a financial collateral arrangement forms part, or, in the absence of any such provision, any statutory rule by which, on the occurrence of an enforcement event, whether through the operation of netting or set-off or otherwise:

(i) the obligations of the parties are accelerated so as to be immediately due and expressed as an obligation to pay an amount representing their estimated current value, or are terminated and replaced by an obligation to pay such an amount; and/or

(ii) an account is taken of what is due from each party to the other in respect of such obligations, and a net sum equal to the balance of the account is payable by the party from whom the larger amount is due to the other party

The mechanism resembles the abovementioned account current as defined in sec. 355 HGB: Like there, the result is in both cases that a multitude of obligations and claims are merged into one remaining claim. And it is only this one that ultimately is to be served. Unlike the account current, however, such merger takes place at a close-out netting agreement not in certain time

44 Cf. www.isda.org. In its own words, its achievements are: "Since its founding in 1985, the International Swaps and Derivatives Association has worked to make over-thecounter (OTC) derivatives markets safe and efficient. ISDA's pioneering work in developing the ISDA Master Agreement and a wide range of related documentation materials, and in ensuring the enforceability of their netting and collateral provisions, has helped to significantly reduce credit and legal risk. The Association has been a leader in promoting sound risk management practices and processes, and engages constructively with policymakers and legislators around the world to advance the understanding and treatment of derivatives as a risk management tool." On ISDA, see also Jordan (ed.) International Capital Markets, 2014, p. 17 (2.19), 31 (3.01), 270 (11.09).

45 See Soltysinski, The Demise of the Principle of Equality of Economic Actors in Private Law, in: Govaere/Hanf (eds.), Scrutinizing Internal and External Dimensions of European Law, Liber Amicorum Paul Demaret Vol. 1, 2013, p. 423, 429 ff.; Schwarcz/Sharon, The Bankruptcy-Law Safe Harbor for Derivatives: A Path-Dependence Analysis, 71 Washington and Lee L.R. 1, 18 (2014).

$46 \mathrm{Jahn} /$ Fried, MüKo-InsO, 3rd ed. 2013, $\mathbb{\$} 104$ marg. no. 152 (translated by the present author). See also Berger, Lösungsklauseln im Insolvenzfall, in: Kölner Schrift zum Insolvenzrecht, 3 rd ed., 2009, p. 325, 342 f.; v.Hall, Insolvenzverrechnungin bilateralen Clearingsystemen, 2010, $149 \mathrm{ff}$. 
intervals but on the event of an enforcement occurrence. The determination of such an occurrence has contractually to be fixed. The same is true for the consequences, but in this regard there are usually two alternatives chosen: either automatic termination or the need for a declaration to terminate. The "Rahmenvertrag für Finanztermingeschäfte" (German Master Agreement for Financial Derivative Transactions) provides in its No. 7(2):47 "The contract terminates without declaration in case of insolvency. Such case is given when and if a bankruptcy or insolvency petition is filed with regard to one party and this party has either filed the petition herself or if she is illiquid or in a situation that justifies the opening of such a proceeding."

Accordingly, the netting mechanism is composed of several elements: (1) the termination of all pending, i.e. not yet fully performed transactions covered by the Master Agreement, (2) the valuation of each party's claims on the basis of hypothetical or real replacement transactions (expressed in monetary terms), and (3) the final offsetting of all covered positions with the result of one single claim for one of both contractual parties (in the money). ${ }^{48}$

\section{b. Insolvency larw}

Taking the stance of the abovementioned wisdom of the pari passu principle ( $\mathrm{B}$ III 3), the close-out netting clause and its effects make some bells ringing in the head of an insolvency lawyer. Not only that this clause is a classic example for a so called ipso-facto clause, ${ }^{49}$ the right to termination does also raise issues of an insolvency administrator's avoidance powers.

a.) Ipso facto-clauses are definitely attractive for many (if not all) contract parties; after all, they provide a possibility to escape from the harsh conse-

47 “Der Vertrag endet ohne Kündigung im Insolvenzfall. Dieser ist gegeben, wenn das Konkurs- oder ein sonstiges Insolvenzverfahren über das Vermögen einer Partei beantragt wird und diese Partei entweder den Antrag selbst gestellt hat oder zahlungsunfähig oder sonst in einer Lage ist, die die Eröffnung eines solchen Verfahrens rechtfertigt.” A similar rule is provided for, for instance, in No. 6(1)(b), 2nd sent. of the European Master Agreement. Further references at Jahn/Fried (as in previous fn), marg. no. $166 \mathrm{f}$.

48 Cf. Schneider, Netting und Internationales Insolvenzrecht, in: Kohler/Obermüller/Wittig (eds.), Kapitalmarkt - Recht und Praxis, Gedächtnisschrift für U. Bosch, 2005, p. 197, 198.

49 On this clause, in the general insolvency context, Jacoby, Lösungsklauseln in der Insolvenz, ZIP 2014, 649 ff.; Paulus/Berberich, National Report for Germany, in: Faber/ Vermunt/Kilborn/van der Linde (eds.), Treatment of Contracts in Insolvency, 2013, 9.109 ff.; Berger (as in fn. 46), p. 325 ff.; Paulus, Verbindungslinien zwischen Insolvenzrecht und Privatautonomie, in: Prütting/Vallender (eds.), Insolvenzrecht in Wissenschaft und Praxis, Festschrift Uhlenbruck, 2000, p. 33, 45 ff. 
quences of the egalitarian insolvency proceeding. But since insolvency law is predominantly irremediable a conflict arises between its mandatory application and the contractual possibility. A closer look into German insolvency law reveals that the resolution of this conflict has many shades. ${ }^{50}$ However, the general rule is sec. $119 \mathrm{Ins} \mathrm{O}$ pursuant to which agreements are invalid when and if they deprive the insolvency administrator of, i.a., its right ${ }^{51}$ to choose between termination and continuation of a contract. Based on this rule and its underlying policy, the German Supreme Court ${ }^{52}$ has decided only recently that ipso facto clauses in energy-supply contracts are invalid.

b.) The abovementioned close-out netting clause displays another insolvency pitfall, its potential avoidability by the actio Pauliana. After all, this timehonored insolvency instrument ${ }^{53}$ is designed in a way to prevent certain preinsolvency activities, particularly those from strong creditors, which effectuate a benefit for them when compared with their fellow creditors and their equal treatment in an insolvency proceeding. Accordingly, these avoidance powers serve, among others, the purpose of applying the par condicio creditorum already in the pre-commencement period. ${ }^{54}$ Thus, if the counterparty of a close-out netting agreement is given the right to terminate the contract one might assume that any exercise of such right by a creditor is subject to avoidability. This is all the more likely as the avoidance powers of German insolvency law have reached a level of aggressiveness by now which creates a

50 Cf. Jacoby (as in previous fn). See, additionally, IMF, Orderly and Effective Insolvency Procedures - Key Issues, 1999, p. 39.

51 Sec. $103 \mathrm{InsO}$ (as in fn. 40).

52 BGH, Dec. from 15 November 2012 - IX ZR 169/11, ZIP 2013, 274; with comment by Huber, Unwirksamkeit von insolvenzbedingten Lösungsklauseln - Vertragspraxis, was nun?, ZIP 2013, 493; Knof, Insolvenzbedingte Lösungsklauseln auf dem Prüfstand, DB 2013, 1769; Löffler, Insolvenzabhängige Lösungsklauseln ade? - Auswirkungen der BGH-Rechtsprechung auf Energielieferungs-Rahmenverträge, BB 2013, 1283; Kliebisch/Linsenbarth, Insolvenzsicherung bei Rahmenverträgen über Finanztermingeschäfte im Lichte der BGH-Entscheidung zur Unwirksamkeit insolvenabhängiger Lösungsklauseln, DZWIR 2013, 449; Braegelmann, Insolvenzabhängige Lösungsklauseln im Visier des BGH, KSI 2013, 259; Wellensiek/Scharfenberg, Das Ende von insolvenzabhängigen Lösungsklauseln für Energielieferungsverträge - Übertragbarkeit auf das Bauvertragsrecht bei Vereinbarung der VOB/B?, DZWIR 2013, 317. On EFET see infra in fn. 59.

53 See Willems, Actio Pauliana und fraudulent conveyances, 2012, p. 20 ff.; additionally, Ankum, De Geschiedenis der “Actio Paulina” (l'histoire de l'action Paul\#Imitpunkt\#enne), 1962; Grevesmübl, Die Gläubigeranfechtung nach klassischem römischen Recht, 2003.

54 On this very recently, see Bork, Anfechtung als Kernstück der Gläubigergleichbehandlung, ZIP 2014, $797 \mathrm{ff}$. 
broad front of lobbying for a drastic cut-back of these powers (the end of which efforts are as of now still an open issue). ${ }^{55}$

c.) However, sec. $104 \mathrm{Ins}^{56}$ rescues financial institutions from these and from further risks. Not only that this rule excludes the administrator's right to choose between termination and continuation - in the common banking parlance: the cherry picking right ${ }^{57}$ (note that this very "cherry picking" is - on purpose! - permitted against all other counterparties outside of financial contracts! it is actually seen as one of the essential peculiarities of almost any insolvency law!) $-;^{58}$ this rule is commonly understood and interpreted as additionally excluding an administrator's avoidance powers, too. It is argued ${ }^{59}$ that the exclusion of the administrator's right of choice implicitly excludes also any detriment for the creditors when and if a termination right is applied. This is essential as, pursuant to sec. $129 \mathrm{Ins} \mathrm{O}$, any avoidability is dependent on a legal act with a detrimental effect for the general unsecured creditors; accordingly, without detriment there is no avoidability.

But it is not just this domestic rule that guarantees protection. The German legislator did not fail to comply with the order expressed in art. 7 of the abovementioned Financial Collateral Directive:

1. Member States shall ensure that a close-out netting provision can take effect in accordance with its terms:

(a) notwithstanding the commencement or continuation of winding-up proceedings or reorganisation measures in respect of the collateral provider and/or the collateral taker; and/or

(b) notwithstanding any purported assignment, judicial or other attachment or other disposition of or in respect of such rights.

55 Cf. Marotzke, Vertrauensschutz kontra Gesamtgläubigerinteresse - Gedanken zu Auslegung und Reform des Insolvenzanfechtungsrechts, ZInsO 2014, 417 ff.; idem, Formulierungsvorschläge für eine "kleine" Reform des Insolvenzanfechtungsrechts, ZInsO 2014, 745 ff. See, additionally, Paulus, Zur Auslegung anfechtungsrechtlicher Vorschriften, FS G.Fischer, 2008, p. $445 \mathrm{ff}$.

56 It is worthwhile noticing that this section entered into force as early as 1994, whereas most of the rest of the Insolvency Ordinance did so 1999!

57 Just see Obermüller, Insolvenzrecht in der Bankpraxis, 8th ed., 2011, p. 668 (3.1001); Schneider (as in fn. 48), p. 198; Soltysinski (as in fn. 45), p. 427.

58 Cf. Berger (as in fn. 46), p. $346 \mathrm{ff}$; Jahn/Fried (as in fn. 46), $\$ 104$ marg. no. $169 \mathrm{f}$;; Köndgen in: Kübler/Prütting/Bork, InsO-Kommentar, $\$ 104$ marg. no. 39, 42.

$59 \mathrm{Jahn} /$ Fried (as in fn. 46), $\mathbb{1} 104$ marg. no. 170 b; Zimmer/Fuchs, Die Bank in Krise und Insolvenz, ZGR 2010, 597, 634. Against: Köndgen in: Kübler/Prütting/Bork, InsOKommentar, $\mathbb{\$} 104$ marg. no. 39, 42. A broad discussion will be found in Riewe, Die EFET-Rahmenverträge für den Handel mit Strom und Erdgas - Standard-Vertragsbestimmungen auf dem Prüfstand des deutschen und des internationalen Privatrechts (Diss., forthcoming in 2014), at Chapter 4 E. 
2. Member States shall ensure that the operation of a close-out netting provision may not be subject to any of the requirements that are mentioned in Article 4(4), unless otherwise agreed by the parties.

Leaving aside the last paragraph with its surprising preponderance of agreements over insolvency rules (we will come back to this shortly in the context of the proposed art. 6 a European Insolvency Regulation (EIR)), it is also remarkable to read the self-imposed obedience of the European legislator towards the finance industry: Member states are to exempt close-out netting effects - as described supra - from any insolvency impediments. The principles of insolvency law are to step back from the business concept of that industry! To say the least: that is quite unique and unusual.

Because insolvencies have nowadays cross-border effects to an increasing degree, the mandate of that art. 7 of the Financial Collateral Directive has to be fulfilled in this regard, too. The German legislator did so in sec. 340 InsO and in art. $102 \mathrm{~b}$ of the Einführungsgesetz zur Insolvenzordnung. ${ }^{60} \mathrm{But}$ also the German Indenture Bond Act (Schuldverschreibungsgesetz $=$ SchVG) has in its sec. 19 par. 1, 2nd s. a respective rule so that the protection is rather allencompassing. But obviously not enough yet: Since the European legislator, too, is kept busy with protective work. Not only that art. 25 of the Credit Institutions' winding-up Directive ${ }^{61}$ has netting agreements governed by the lex contractus rather than the lex concursus; the same shall now be inserted as art. $6 a$ into the revised EIR.

The latter is noteworthy in at least two aspects: Firstly, the exclusion of the otherwise applicable lex concursus opens avenues for choosing a particularly close-out netting friendly law and almost urges the participants, thus, to do what the rest of the EIR explicitly tries to suppress - namely forum shopping! ${ }^{62}$ Secondly, when and if the special credit institutions' insolvency legislation contains already a respective rule (the abovementioned art. 25), and when and if the EIR explicitly excludes such financial institutions from its applicability, ${ }^{63}$ it is irritating that such a rule shall nevertheless be included into the EIR. This raises suspicion that the use of the protection for close-out netting is benefitting no longer just financial institutions but many more

60 The originally envisaged sec. 104 a InsO became never adopted; cf. Jahn/Fried (as in fn. 46), $\$ 104$ marg. no. $180 \mathrm{~m}$.

61 Directive 2001/24/EC of the European Parliament and of the Council of 4 April 2001 on the reorganisation and winding up of credit institutions

62 Cf. Recital 4 of the EIR: It is necessary for the proper functioning of the internal market to avoid incentives for the parties to transfer assets or judicial proceedings from one Member State to obtain a more favourable legal position (forum shopping).

63 Cf. art. 1 par. 2 EIR. 
who manage to fall under the definition of this form of netting. We will come back to this below sub e).

d.) Close-out netting experiences, thus, a special insolvency treatment. To get the entire picture visible, however, it is still necessary to explain as to how this special treatment constitutes a privilege. This becomes particularly evident by looking at a hypothetical (taken from Virgós/Garcimartín ${ }^{64}$ ) which demonstrates the enormous reduction of the general insolvency risk - meaning the risk to suffer a loss from one's counterparty's insolvency:

$A$ and $B$ have entered into several derivative transactions, for example multiple interest rate swaps. Numerous mutual payment obligations result from these transactions. If $B$ defaults on one of them, a close-out netting arrangement allows A (i) to terminate all transactions early, (ii) to assess the value of each transaction (some of which may have a positive replacement value and others a negative one), and (iii) to offset these amounts. Let us imagine that the parties have entered into three transactions: Transaction 1 and 2 had a positive value for B of 8 (B was "in the money") and transaction 3 had a positive value for A of 10 (A was "in the money"). In this example, the reciprocal payment obligations are computed so as to result in a single payment obligation of $\mathrm{B}$ to $\mathrm{A}$ : A only has to receive 2 from $\mathrm{B}$ instead of paying 8 and requesting 10 from $\mathrm{B}$.

Expressed in real life figures, the actual savings are even more impressive than those given in the hypothetical: According to Paech, ${ }^{65}$ the benefits for the year 2009 (more precisely: June of that year) are as follows: The nominal total amount of globally all OTC finance services added up to 605 trillion USD. The gross risk of non-payment of these financial services would have amounted to 25 trillion USD. The existence of close-out netting agreements and their insolvency proofness, however, reduced the net non-payment risk to 3,7 trillion USD. ${ }^{66}$ Indeed, this instrument is quite effective in achieving what it is designed for: the reduction of the insolvency risk!

e.) At this point, it should have become sufficiently clear that the treatment of close-out netting agreements under German (and many other countries') insolvency law(s) constitutes, in fact, a privilege. This, in and for itself, could be seen as sufficient reason to oppose it for principal reasons. After all, when the Insolvency Ordinance proclaimed the complete abolition of privileges and

64 Virgós/Garcimartín, Close-out netting, Insolvency and Resolution of Financial Institutions in the EU: A Conflict of Law Analysis, in: Santen/van Offeren (eds.), Perspectives on international insolvency law - A tribute to Bob Wessels, 2014, p. 151, 153.

65 Paech, Netting, Finanzmarktstabilität und Bankenrestrukturierung - Die Notwendigketi eines internationalen zivilrechtlichen Standards, Wertpapier-Mitteilungen (WM) 2010, 1965, 1966 with reference to par. 117, 118, 139, 188 of the BIS paper 'Strengthening the resilience of the banking sector, Dec. 2009; available at: http://www.bis.org/publ/ bcbs164.pdf? noframes=1.

66 See also Paech (as in previous fn), p. 1966 (reduction of the otherwise necessary securitization to $15 \%)$. 
when even the tax authorities have been deprived of their previous privilege why then should financial institutions keep it. ${ }^{67}$

As justifiable as such approach might be, the opposition yet can be grounded on much more solid ground and on much harder facts. To discover them, it is necessary to bear in mind the seemingly banal fact that those who benefit from that privilege are human beings and share, therefore, with all others certain behavioural patterns which display the potential of a downside; here we come back to what has been stated supra at B III 3. It is a well known fact that privileges induce those who enjoy it to riskier behavior and reduced attention, and those who do not enjoy it to get nevertheless "a piece of the cake".

It is, thus, not really surprising to find all these (and a few more) behavioral patterns in a list in a Note compiled by the Secretariat of UNCITRAL's Working Group V. ${ }^{68}$ This UN Commission has recently - in December 2013 discussed on occasion of a public conference whether future work should be devoted to the role of close-out netting and the safe harbors in the general insolvency context. In preparation for this event the said Note states that the insolvency proofness of close-out netting agreements might cause the following effects:

- the risk that creditors who are not true financial counterparties side step the insolvency process;

- possible disincentives to monitor the credit strength of trading partners;

- the potential incentive to frame transactions as financial contracts and obtain a de facto undisclosed security interest;

- the potential unfairness to the general body of creditors (i.e. the inequitable distribution of insolvency loss) and harm to the estate;

- the risk of abuse of the insolvency process by "empty creditors" (whose economic interests diverge from their right to vote their claim) and potential harm to restructuring attempts; and

- the risk of expansion of exemptions beyond their intended scope.

The issues quoted are those that the secretariat has spotted in its preparatory work for this conference. Not only that obviously attempts are made ${ }^{69}$ to

67 Or even: have it extended! On this, see Schwarcz/Sharon (as in fn 42) for the evolution of the privilege in the USA. A similar study on the German development is to appear later this year by the present author.

68 Cf. A/CN.9/WG.V/WP.117, p. 13 ff, available at: http://daccess-dds-ny.un.org/doc/ UNDOC/LTD/V13/871/05/PDF/V1387105.pdf?OpenElement.

69 As a matter of fact, big law firms nowadays have teams of lawyers whose primary task it is to design contracts in a way that they fall under the safe harbor exceptions. 
define certain transactions and agreements in a way that they fall under the protective shield originally designed exclusively for the benefit of credit institutions $^{70}$ - this "explains" why the abovementioned (sub c) special norm shall be included in the European Insolvency Regulation (art. 6a ${ }^{71}$ ) -; those risky behaviors include also what is commonly known as moral hazard.

What might be seen from an academic perspective as a theoretical issue has been subject to intensive research. The result of which is that moral hazard and its dangerous implications is not only real; it is, as a matter of fact, also one of the most prominent triggers for the last global financial crisis of 2008 - it has been shown (most impressive by Prof. Roe ${ }^{72}$ ) that the failures of Bear Stearnes, AIG, and Lehman Brothers ${ }^{73}$ were facilitated and acerbated by the safe harbor rules in the insolvency legislation. ${ }^{74}$ They undermined market discipline in the foregoing years and there are only few indications, if any, that this has changed ever since.

\section{c. Privileges as a lender for sovereigns}

Seen from an academic insolvency law perspective one wonders how it is possible that in a Code which was enacted with the explicit pride of having abolished all privileges and having established the time-honored principle of the creditors' equal treatment such a super privilege not only has been kept but also so far never been seriously disputed. Leaving aside the hearsay rumor of the existence of around 1700 respective lobbyists in Brussels alone, another privilege for financial institutions comes to mind which has insolvency implications insofar as it elevates those institutions in the area of "too big to fail".

To be sure, legislators in the larger financial centres of this world have reacted to the last crisis and have enacted endless new legislations dealing with the

70 See, for instance, the discussion at Jahn/Fried (as in fn. 46), $\$ 104$ marg. no. $174 \mathrm{ff}$.

71 On this legislative proposal, see the opposing statement of the Belgium and French delegation from 6 March 2014-7377/14 (JUSTCIV 64; CODEC 672) as being in certain contradiction with the intentions of the proposed EU Bank Recovery and Resolution Directive.

72 Roe, The Derivatives Market's Payment Priorities as Financial Crisis Accelerator, 63 Stan. L. Rev. 539 ff.; idem, Derivatives Markets in Bankruptcy, Comp. Econ. Studies 2013, $519 \mathrm{ff}$.

73 It is said that the chaotic close-outs in mid-September 2008, i.e. around the bankruptcy filing of Lehman, had cost this bank something like 50 billion Dollars in value.

74 See, in addition to Roe (as in fn. 72), Skeel, Bankruptcy Boundary Games, 4 Brook. J. Corp.Fin. \& Com. L., p. 1 ff (2009); Lubben, Repeal the Safe Harbors, 18 Am. Bankr. Inst. L.R. 319 ff. (2010); Skeel/Jackson (as in fn 26), p. 166 ff.; Soltysinski (as in fn. 45); Schwarcz/Sharon (as in fn. 45). 
rescue and liquidation of financial institutions. However, when the European and the German legislator alone have introduced and planned more than 65 legislative projects since $2008^{75}$ and when these efforts are still ongoing, suspicion arises that this hyperactivity misses the point. Innumerable new instruments rarely achieve the goal (too many cooks spoil the broth). The alleged goal is rather clear: to prevent systemic effects when a bank fails and to inhibit the tax payer from paying for the failures of bankers.

But there is a complication in this scenario which makes it rather difficult to achieve this goal. The very legislator who is in charge of finding clear rescue and winding-up solutions for failing banks has a fundamental interest in saving them. ${ }^{76}$ Since sovereigns, at least within the European Union, are heavily dependent on banks as their lenders. In order to foster this relationship, the borrowing sovereign uses its powers as legislator to grant several privileges to the financial institutions which make this borrower particularly attractive for lending businesses. ${ }^{77}$ Suffice it to mention the so called large exposure regime (LER):

See art. 111 of Directive 2006/48/EC: ${ }^{78}$

A credit institution shall not incur an exposure, after taking into account the effect of the credit risk mitigation in accordance with Articles 112 to 117, to a client or group of connected clients the value of which exceeds $25 \%$ of its own funds.

This is a prudent provision based on the insight that dependency on a single customer might lead to dangerous consequences. However, only two articles further down, art. 113 establishes exemptions - one of them being lending to a central government! This is an invitation gladly accepted by many financial institutions to adhere to what is commonly known as a "home bias" of bank lending, i.e. being exposed to one's home central government to 80 or even $90 \%$ ! The pernicious consequence of such home bias is, however, a procyclicality in times of crises such as the one experienced in Europe since 2010. They have shown the interrelatedness of failing banks knocking down sovereigns and vice versa.

75 Cf. Höche, Bankenregulierung zur Bewältigung der Finanzmarkt- und Staatsschuldenkrise, in: Bankenregulierung, Insolvenzrecht, Kapitalanlagegesetzbuch, Honorarberatung - Schriftenreihe der Bankrechtlichen Vereinigung vol. 35, 2013, p. $3 \mathrm{ff}$.

76 On the following, see already Paulus, Staatenpleiten und Bankenpleiten: eine gewollte Mesalliance, KTS 2013, 155 ff.; idem (as in fn. 29).

77 Very informative in this context the report presented by the Wissenschaftlicher Beirat des Bundesministeriums der Finanzen from February 2014: Der Staat als privilegierter Schuldner - Ansatzpunkte für eine Neuordnung der öffentlichen Verschuldung in der Europäischen Währungsunion (accessible in internet).

78 Directive 2006/48/EC of the European Parliament and the of the Council of 14 June 2006 relating to the taking up and pursuit of the business of credit institutions. 
Under these conditions it is hard to believe that those 65 (and more) legislative activities really will solve the problem. The legislator is caught in something akin to a conflict of interest. An effective expulsion of a bank from the market might cause that same legislator's insolvency! Therefore, it is to be feared that the "too big to fail" issue will remain on the agenda for quite some time to come.

\section{Conclusions}

Any realistic approach to the issues addressed in the preceding pages has to encounter that a simplistic call for abolition of all those privileges would cause catastrophic consequences. If the present system stands at all to improvements - be it remembered that the once intended introduction of a privileged status for licences by means of the envisaged sec. 108 a InsO was fiercely contested ${ }^{79}$ and repelled as being in breach of the basic principle of the par condicio creditorum $^{80}-$, they should certainly be made carefully and step by step. But they definitely should be done!

One of these improvements would be the reduction and ultimate abolition of the LER. Another one would the examination of the consequences of a restriction of the privilege for close-out netting in insolvency law. After all, the study of Skeel and Jackson ${ }^{81}$ demonstrates that not much would change when offsetting would be permissible furtheron as well as unavoidability of Master Agreements when entered into prior to the suspect periods of the general avoidance rules. A third option would be to have the financial institutions pay (at least something) for enjoying their privileges. ${ }^{82}$

But the very first step of all such improvements is to become aware of the mere existence of such privilege. As banal as this statement might sound, it is not an

79 See just $v$. Wilmowsky, Gegen einen $\$ 108$ a InsO für Lizenzverträge - Die Pflichten des Lizenzgebers (Vermieters, Verpächters) nach Überlassung des Gegenstands zur Nutzung, NZI 2013, $377 \mathrm{ff}$. See, however, an application of a not uncommon tactics within Europe in Holzer, Die Arbeiten der UNCITRAL zur Insolvenzfestigkeit von Lizenzverträgen, NZI 2014, $337 \mathrm{ff}$.

80 Note that the most recent decisioning of the BGH, dec. from 19 July 2012 - I ZR 70/10, ZIP 2012, 1561 - M2Trade; dec. from 19 July 2012 - I ZR 24/11, ZIP 2012, 1671 - Take Five, might ultimately lead to making the discussion obsolete when and if it becomes clarified that licence rights are to be seen as rights in rem, cf. Hirte, Sublizenzen in der neueren Rechtsprechung des I. Zivilsenats des BGH - und ihre Auswirkungen auf die Debatte um die Insolvenzfestigkeit von Lizenzen, ZInsO 2013, $1770 \mathrm{ff}$.

81 As in fn. 25.

82 Cf. Perotti, Systemic liquidity risk and bankruptcy exceptions, DSF Policy Paper, No. 8, 2010; idem, The Roots of Shadow Banking, 2013. Note that the underlying idea of this proposal coincides with what has been said supra (in fn. 30 ) about Islamic finance law: there, too, diligence is imposed on lenders by exposing them to a personal risk. 
easy task. Since all these abovementioned privileges are quite carefully hidden in overly complicated rules, constructions, and systems. ${ }^{83}$ It appears as if this is a strategy which has been quite successful up to now. The time seems to be ripe to come here, too, to greater transparency and equality.

83 See already Paulus (as in fn. 76), p. 158 ff.; moreover, Schwarcz, The Functional Regulation of Finance (available at: http://papers.ssrn.com/sol3/papers.cfm?abstract_id=2437544) referring in fn. 73 to Bucheit, Did We Make Things Too Complicated?, 27 Int'l Financial L. R. 24 (2008). 